\title{
IMPLEMENTASI VALUE FOR MONEY, INPUT OUTPUT OUTCOME DAN BEST VALUE SEBAGAI ALAT PENGUKURAN KINERJA SEKTOR PUBLIK
}

\author{
Kariyoto \\ Dosen Program Pendidikan Vokasi Universitas Brawijaya Malang,
}

\begin{abstract}
ABSTRAKSI
Pengukuran organisasi sektor publik menjadi penting untuk mengetahui tingkat pencapain pelayanan kepada masyarakat. Kinerja organisasi sektor publik dapat diukur menggunakan alat dan indikator yang sesuai. Tujuan dari penelitian ini adalah untuk mengetahui konsep nilai waktu uang, masukan keluaran hasil, nilai terbaik sebagai indikator pengukuran kinerja sektor publik. Penelitian ini berlokasi di Perpustakaan Universitas Brawijaya Malang. Jenis penelitian melalui studi perpustakaan. Pengumpulan data dilakukan dengan observasi dan dokumentasi buku yang berhubungan dengan kinerja organisasi sektor publik. Analisis data digunakan reduksi data, penyajian data, dan penarikan kesimpulan atau verifikasi data. Hasil penelitian menunjukkan bahwa nilai waktu uang, masukan keluaran hasil dan nilai terbaik dapat dipakai sebagai alat pengukuran kinerja organisasi sektor publik.
\end{abstract}

Kata Kunci: implementasi, nilai waktu uang, masukan keluaran hasil, nilai terbaik

\begin{abstract}
Measurement of public sector organizations become important to know the level of achievement of service to the community. The performance of public sector organizations can be measured using the appropriate tools and indicators. The purpose of this study was to determine the concept of time value of money, the input output results, the best value as an indicator of public sector performance measurement. This research is located in the Library of the University of Brawijaya. This type of research through library studies. The data collection is done by observation and documentation of books relating to the performance of public sector organizations. The data analysis used data reduction, data presentation, and conclusion or data verification. The results showed that the time value of money, the input and the output of the best value can be used as a performance measurement tool of public sector organizations.
\end{abstract}

Keywords: implementation, value for money, input output results, best value

\section{PENDAHULUAN}

Pemilihan dan penentuan instrumen pengeukuran kinerja dan strategi yang akan diterapkan tergantung pada kondisi intemal dan ekstemal yang dimiliki dan dihadapi oleh organisasi. Strategi organisasi harus dijabarkan dalam bentuk program dan kegiatan untuk menjamin bahwa program dan kegiatan yang telah diterapkan tersebut dilaksanakan dengan baik sesuai dengan tujuan organisasi, maka diperlukan alat pengukuran kinerja yang tepat.

Alat pengukuran kinerja organisasi sektor publik berfokus pada bagaimana strategi dapat dilaksanakan secara efektif dan efisien sehingga tujuan organisasi dapat tercapai. Efisiensi dan efektivitas organisasi telah menjadi obsesi dari hampir semua pendekatan ilmu manajemen, baik pendekatan ilmu manajemen klasik maupun pendekatan manajemen ilmiah (scientific management). Perkembangan berbagai teori manajemen menunjukkan bahwa menciptakan organisasi yang efektif dan efisien bukan pekerjaan yang mudah dan sederhana, melainkan sangat rumit dan multidimensional. Oleh karena itu, dalam memilih alat untuk mengukur kinerja organisasi sektor publik harus dapat memastikan organisasi berjalan efektif dan efisien. Alat pengukuran kinerja sektor publik harus didukung dengan perangkat yang lain, yaitu struktur organisasi yang sesuai seperti pengendalian manajemen, manajemen sumber daya manusia, dan lingkungan yang mendukung.

Pada dasarnya alat pengukuran kinerja sektor harus didukung dengan tipe pengendalian manajemen dibagi menjadi tiga kelompok, yaitu pengendalian preventif pengendalian operasional, dan pengendalian kinerja. Pengendalian preventif merupakan pengendalian manajemen yang terkait dengan perumusan strategi dan perencanaan straregis yang dijabarkan dalam program dan kegiatan. Sedangkan, pengendalian operasional merupakan pengendalian manajemen terkait dengan pengawasan pelaksanaa program yang telah ditetapkan melalui anggaran. Dalam 
konteks ini, anggaran sebagai penghubung antara perencanaan dengan pengendalian. Pengendalian kinerja berupa evaluasi terhadap kinerja program dan kegiatan yang telah dilaksanakan sesuai dengan tolok ukur kinerja yang telah ditetapkan. Tolok ukur kinerja digunakan sebagai dasar untuk menilai apakah suatu program dan kegiatan dinyatakan berhasil atau gagal. Untuk menyusun tolok ukur kinerja yang sesuai diperlukan alat pengukuran kinerja. Alat pengukuran kinerja yang andal merupakan kunci sukses dari suatu organisasi. Untuk mendesain alat pengukuran kinerja yang komprehensif diperlukan pemahaman terhadap sistem pengendalian manajemen pada suatu organisasi. Oleh karena setiap organisasi memiliki tujuan dan strategi yang berbeda maka sistem pengendalian manajemen setiap organisasi juga berbedabeda.

\section{METODE PENELITIAN}

Metode penelitian menggunakan pendekatan deskriptif kualitatif (Kariyoto, 2014). Metode ini digunakan untuk mendapatkan pemahaman dan gambaran yang utuh mengenai sebuah fenomena pustaka tentang alat pengukuran kinerja organisasi sektor publik. Pada sesi berikutnya akan dibahas bagaimana keterkaitan sistem pengukuran kinerja dengan fungsi pengendalian manajemen, hubungannya desain sistem pengukuran kinerja dengan sistem pengendalian manajemen, serta menjelaskan beberapa konsep untuk menciptakan sistem pengukuran kinerja yang baik dan implementasinya dalam organisasi sektor publik. Koleksi data dalam penelitian ini dilakukan dengan observasi studi pustaka atau dokumentasi. Peneliti berperan key instruments, kehadirannya diketahui sebagai informan dan bersifat observative non participant (Kariyoto, 2014). Peneliti meninjau dan menelaah konsepkonsep yang menjadi proses design alat pengukur kinerja organisasi sektor publik. Data informasi tambahan digali melalui pengalaman praktis sebagai praktisi akuntansi sektor publik. Oleh karena itu organisasi materi hasil penelitian ini diawali: (1) Pengukuran Kinerja dan Fungsi Pengendalaian Manajemen Organisasi Sektor Publik; (3) Kesesuain Desain Pengukuran Kinerja dengan Desain Sistem Pengendalian Manajemen; (4) Konsep Value For Money Sebagai Instrumen Pengukuran Kinerja; (5) Konsep Dasar Input, Output, dan Outcome; (6) Konsep Best Value; (7) Implementasi Pengukuran Kinerja pada Sektor Publik; (8) Kesimpulan.

\section{PENGUKURAN KINERJA DAN FUNGSI PENGENDALIAN MANAJEMEN ORGANISASI SEKTOR PUBLIK}

Organisasi sektor publik sebagaimana dijelaskan di atas bahwa memerlukan pengendalian manajemen untuk mencapai tujuannya. Pengendalian manajemen sudah melekat dengan keberadaan organisasi. Artinya, fungsi pengendalian manajemen organisasi ada sejak organisasi tersebut berdiri dan akan tetap ada seiring dengan keberlangsungan organisasi. Mahmudi (2007) membagi fungsi pengendalian menjadi dua jenis, yaitu pengendalian formal dan informal. Pengendalian formal dilakukan melalui saluran komunikasi formal berupa aktivitasaktivitas resmi organisasi yang bersifat rutin, seperti perumusan strategi, perencanaan strategis, penganggaran, operasionalisasi anggaran, dan evaluasi kinerja. Pengendalian informal dilakukan melalui jalur komunikasi informal seperti komunikasi langsung, pertemuan informal, diskusi, memo, observasi ke lapangan, jamuan atau disebut juga melalui metode management by walking around. Desain sistem pengendalian manajemen yang baik adalah desain yang mampu menyelaraskan antara pengendalian manajemen formal dan informal.

Pengendalian formal belum tentu lebih baik dibanding dengan pengendalian informal. Pengendalian informal menjadi sangat penting jika dapat menutupi kelemahan yang ada pada pengendalian formal yang diterapkan organisasi tersebut. Organisasi pemerintahan, biasanya lebih menggunakan pengendalian formal. Namun demikian, semenjak adanya konsep New Public Management, pendekatan pengendalian manajemen organisasi sektor publik, terutama pemerintahan, menjadi lebih fleksibel, yaitu kombinasi antara pengendalian formal dan informal.

F. W Taylor dalam bidang akuntansi mengembangkan konsep pengen-dalian dalam akuntansi manajemen. Pengendalian dalam akuntansi manajemen terkait dengan pengendalian biaya dan pengendalian anggaran yang dikendalikan melalui pusat pertanggungjawaban akuntansi. Perkembangan terkini memungkinkan pengendalian biaya dan anggaran tidak secara langsung terkait dengan input atau tidak terbatas pada pengendalian keuangan, sebagaimana konsep pengen-dalian tradisional. Melainkan, pengendalian dapat dilakukan melalui pengendalian aktivitas, Dari konsep ini 
munculah konsep activity-based costing, activity-based budgeting, dan activity-based management.

Konsep dan filosofi pengendalian aktivitas tidak hanya relevan diterapkan untuk organisasi bisnis, tetapi juga dapat diadopsi pada organisasi sektor publik (Mahmudi, 2007). Contoh penerapan dari pengendalian aktivitas pada organisasi sektor publik adalah diterapkannya penganggaran berbasis kinerja (performancebased budgeting) pada pemerintah daerah. Pelaksanaan anggaran berbasis kinerja dimulai sejak dikeluarkannya Kepmendagri nomor 29 Tahun 2002. Penganggaran kinerja menghendaki dikaitkannya setiap mata anggaran dengan program, kegiatan, dan target kinerja. Anggaran dikeluarkan untuk mendanai/membiayai program dan kegiatan serta setiap program dan kegiatan memiliki ukuran dan target kinerjanya. Oleh karena itu, konsep pengendalian aktivitas menuntut adanya sistem pengukuran kinerja. Jadi, keterkaitan antara sistem pengukuran kinerja dan sistem pengendalian manajemen adalah bahwa sistem pengukuran kinerja merupakan bagian dari fungsi pengendalian manajemen.

Sistem pengukuran kinerja sektor publik adalah suatu sistem yang bertujuan untuk membantu manajer publik menilai capaian suatu strategi melalui tolok ukur kinerja yang ditetapkan. Tolok ukur kinerja tersebut dapat berupa pengukuran kinerja keuangan dan nonkeuangan. Pengukuran kinerja ini sangat penting untuk menilai akuntabilitas organisasi dan manajer dalam menghasilkan pelayanan publik yang lebih baik. Akuntabilitas bukan sekadar kemampuan menunjukkan bagaimana uang publik dibelanjakan, tetapi meliputi kemampuan menunjukkan bahwa uang publik tersebut telah dibelanjakan secara ekonomis, ehsien, dan efektif (konsep value for money). Artinya, bahwa setiap rupiah yang dibelanjakan pemerintah harus berdampak terhadap kepentingan dan kebutuhan publik sesuai dengan tuntutan publik, serta dapat dipertanggungjawabkan kepada publik.

Mahmudi (2007: 14) mengidentifikasi tujuan dilakukannya pengukuran kinerja pada organisasi sektor publik untuk: (1) mengetahui tujuan organisasi; (2) menyediakan sarana pembelajaran bagi pegawai; (3) memperbaiki kinerja untuk periode berikutnya; (4) memberikan pertimbangan yang sistematik dalam pembuatan keputusan pemberian reward dan punishment; (5) memotivasi pegawai; (6) menciptakan akuntabilitas publik.

Sedangkan manfaat disusunnya pengukuran kinerja bagi organisasi pemerintahan adalah (Mardiasmo, 2009: 122): (1) memberikan pemahaman mengenai ukuran yang digunakan untuk menilai kinerja manajemen; (2) memberikan arah untuk mencapai target kinerja yang telah ditetapkan; (3) untuk memonitor dan mengevaluasi pencapaian kinerja dan membandingkannya dengan target kinerja serta melakukan tindakan korektif untuk memperbaiki kinerja; (4) sebagai dasar untuk memberikan penghargaan dan hukuman (reward and punishment) secara objektif atas pencapaian prestasi yang diukur sesuai dengan sistem pengukuran kinerja yang telah disepakati; (5) sebagai alat komunikasi antara bawahan dan pimpinan dalam rangka memperbaiki kinerja organisasi; (6) membantu mengidentifikasi apakah kepuasan pelanggan sudah terpenuhi; (7) membantu memahami proses kegiatan instansi pemerintah; dan (8) memastikan bahwa pengambilan keputusan dilakukan secara objektif.

Berdasarkan tujuan dan manfaat di atas, pengukuran kinerja sektor publik dilakukan untuk memenuhi tiga maksud, adalah sebagai berikut (Mardiasmo, 2009: 121): (1) Pengukuran kinerja sektor publik dimaksudkan untuk membantu memperbaiki kinerja pemerintah, maksudnya adalah untuk membantu pemerintah berfokus pada tujuan dan sasaran program unit kerja. Akibatnya, hal ini dapat meningkatkan efisiensi dan efektivitas organisasi sektor publik dalam memberikan pelayanan publik; (2) Pengukuran kinerja sektor publik digunakan untuk pengalokasian sumber daya dan pembuatan keputusan; (3) Pengukuran kinerja sektor publik dimaksudkan untuk mewujudkan akuntabilitas publik dan memperbaiki komunikasi kelembagaan.

Ketiga maksud dilakukannya pengukuran kinerja pada organisasi sektor publik tersebut, mengindikasikan bahwa kinerja organisasi sektor publik memiliki ruang lingkup yang luas dan multidimensional. Akibatnya, tidak ada indikator tunggal yang dapat menggambarkan kinerja organisasi sektor publik secara komprehensif. Hal ini menunjukkan bahwa dimensi output yang dihasilkan oleh organisasi sektor publik lebih banyak yang bersifat intangible output. Untuk itu, pengukuran kinerja keuangan saja tidak cukup untuk mengukur kinerja sektor 
publik, sehingga diperlukan pengukuran kinerja nonkeuangan (Mardiasmo, 2009).

\section{KESESUAIAN DESAIN PENGUKURAN KINERJA DENGAN DESAIN SISTEM PENGENDALIAN MANAJEMEN}

Pengukuran kinerja merupakan alat bagi manajemen untuk menilai keberhasilan organisasi. Dalam organisasi sektor publik, keberhasilan organisasi dinilai dari kemampuan organisasi ialam menyediakan pelayanan publik yang murah dan berkualitas. Apabila organisasi sektor publik tersebut mampu menyediakan pelayanan publik yang murah dan berkualitas, maka organisasi tersebut akan memperoleh kepercayaan dan dukungan publik. Kepercayaan dan dukungan publik ini penting bagi organisasi sektor publik, karena mereka akan mempertanggung jawabkan kepada publik atas penggunaan dana yang diperolehnya dari publik. Mengukur keberhasilan organisasi sektor publik tidaklah mudah seperti mengukur keberhasilan pada organisasi bisnis. Terdapat beberapa hal yang perlu dijawab untuk mengetahui keberhasilan suatu organisasi sektor publik, yaitu sebagai berikut (Mahmudi, 2007: 13). Apa yang sebenarnya akan diukur: (1) Skala atau ukuran apa yang akan digunakan? (2) Berapa toleransi kesalahan yang akan diterima? (3) Siapa yang akan mengukur? (4) Untuk siapa informasi kinerja tersebut dan apa yang akan mereka lakukan dengan laporan hasil kinerja tersebut?

Organisasi sektor Publik untuk menjawab pertanyaan-pertanyaan tersebut, diperlukan koherensi, keterpaduan, dan keterkaitan antar-elemen sistem pengendalian manajemen dan kesesuaian antara proses pengendalian manajemen dan struktur pengendalian manajemen. Desain sistem pengendalian yang efektif harus mempertimbangkan beberapa faktor. Sudrajat (2007) menyebutkan faktor-faktor yang perlu menjadi pertimbangan dalam menyusun sistem pengendalian manajemen, yang namanya juga akan memengaruhi dalam menyusun sistem pengukuran kinerja, yaitu sebagai berikut.

Desain sistem pengendalian tergantung pada karakteristik lingkungan yang dihadapi. Tidak ada sistem pengendalian manajemen yang terbaik, yang ada hanyalah apakah sistem pengendalian manajemen yang diterapkan cocok atau tidak dengan karakteristik organisasi. Karakteristik lingkungan yang dihadapi akan mempengaruhi efektivitas pengendalian manajemen yang digunakan. Oleh karena itu, pemahaman terhadap karakteristik lingkungan organisasi merupakan dasar untuk merancang sistem pengendalian yang efektif. Pendekatan ini dinamakan dengan pendekatan kondisional atau kontinjensi (contigency approach). Pendekatan kontinjensi diperlukan untuk menciptakan sistem pengukuran kinerja yang andal. Dalam konteks organisasi sektor publik, yang memiliki karakterisrik lingkungan dengan ketidakpastian lingkungan yang tinggi, sasaran organisasi yang samar, dan banyaknya variasi kepentingan dari berbagai pihak (Untoro, 2010), menjadikan pendekatan kontinjensi sangat relevan digunakan untuk menyusun sistem pengukuran kinerja.

Paradigma, merupakan peta yang menggambarkan kondisi lingkungan yang dihadapi oleh suatu organisasi. Paradigma akan memengaruhi cara anggota di dalam organisasi untuk bersikap dan bertindak. Berdasarkan suatu paradigma tertentu, suatu sistem dirancang sehingga dapat mengorganisasi berbagai sumber daya untuk mencapai tujuan sistem, untuk itu paradigma yang dianut oleh anggota organisasi juga akan menjadi pertimbangan dalam menyusun sistem pengukuran kinerja.

Sistem terdiri atas dua bagian, yaitu proses dan struktur, proses terkait dengan tahapan yang harus dilalui, sedangkan struktur terkait dengan komponenkomponen yang berkaitan satu dengan yang lainnya secara bersama-sama. Proses dan struktur pengendalian manajemen, sebagaimana dijelaskan di atas, berpengaruh terhadap efektivitas sistem pengendalian manajemen. Faktor proses dan struktur inilah yang kemudian harus saling terpadu dan berintegrasi dengan sistem manajemen kinerja. Untuk menciptakan organisasi yang memiliki kinerja tinggi diperlukan sistem manajemen kinerja yang terintegrasi dengan sistem pengendalian manajemen (Mahmudi, 2007), pada proses pengendalian manajemen maupun pada struktur pengendalian manajemen. Integrasi sistem manajemen kinerja dengan kedua bentuk pengendalian manajemen pada organisasi sektor publik. Keahlian manajerial (managerial skill). Keahlian atau kompetensi diperlukan untuk menjalankan sistem yang telah dirancang. Meskipun, sistem telah disusun dengan baik, namun jika anggota di dalam organisasi tersebut 
banyak yang tidak berkompeten untuk melaksanakannya, maka sistem tersebut tidak bisa berjalan.

$$
\text { Peranan sistem manajemen }
$$

kinerja tampak pada tahap perencanaan strategis, implementasi, dan evaluasi kinerja. Tolok ukur kinerja pada program dan pelaksanaan anggaran harus sesuai dengan rancangan tolok ukur kinerja yang telah ditetapkan pada rencana strategis, yang merupakan penjabaran dari visi, misi, tujuan, dan strategi organisasi pada tahap perencanaan strategis. Rencana strategi berisi tentang sasaran strategis yang akan dicapai oleh organisasi, hasil (outcome) dan indikator kinerja, inisiatif strategis serta target kinerja. Pada tahap implementasi, organisasi melakukan pengukuran kinerja untuk mengetahui tingkat pencapaian strategi dalam mencapai tujuan organisasi. Ukuran kinerja pada tahap implementasi harus mengacu pada ukuran kinerja yang diretapkan pada tahap perencanaan strategis agar tidak terjadi penyimpangan dan ketidakadilan dalam memberikan penilaian terhadap kinerja manajer.

Begitu juga dengan struktur organisasi yang merupakan bagian dari struktur pengendalian manajemen. Integrasi sistem manajemen kinerja dengan struktur pengendalian manajemen terlihat pada kesesuaian sistem pengukuran kinerja dengan struktur organisasi yang terdiri dari pusat-pusat pertanggungjawaban. Oleh karena itu desain sistem pengukuran kinerja harus sesuai dengan desain pengendalian manajemen.

\section{KONSEP VALUE FOR MONEY PADA PENGUKURAN KINERJA}

Konsep value for money merupakan konsep untuk mengukur ekonomi, efektivitas, dan efisiensi kinerja program, kegiatan dan organisasi. Konsep value for money (VFM) adalah konsep yang penting dalam organisasi sektor publik sehingga sering kali disebut dengan inti dari pengukuran kinerja sektor publik. VFM juga mengandung arti sebagai penghargaan terhadap nilai uang. Hal ini berarti setiap rupiah harus dihargai secara layak dan digunakan sebagaimana mestinya (Mahmudi, 2007). Selain konsep VFM, terdapat juga pendekatan yang lebih baru dalam manajemen kinerja sektor publik yaitu konsep best practice atau best value yang merupakan perluasan dari konsep VFM.

Konsep VFM untuk diimplementasikan pada pengukuran kinerja diperlukan pengembangan indikator kinerja. Indikator kinerja dikembangkan dari variabel kunci yang berhasil diidentifikasi oleh organisasi untuk unit kerja yang terkait, untuk dapat diketahui tingkat capaian kinerjanya. Indikator kinerja tersebut kemudian dibandingkan dengan target kinerja atau standar kinerja. Pada dasarnya pengembangan indikator kinerja meliputi pengembangan indikator kinerja makro dan mikro. Indikator kinerja makro digunakan pada tingkat korporat atau organisasi induk, sedangkan indikator kinerja mikro digunakan pada tingkat unit kerja. Indikator kinerja untuk tiap-tiap unit kerja pada dasamya dikembangkan secara unik atau khusus sesuai dengan karakteristik unit tersebut, akan tetapi dapat juga dikembangkan indikator yang sifatnya standar yang berlaku untuk semua unit. Namun demikian, standar kinerja untuk unit kerja tidak bisa semuanya dibuat secara seragam karena masing-masing unit kerja pasti memiliki karakteristik dan keunikan yang berbeda-beda.

Begitu juga dengan orientasi pengembangan indikator kinerja hendaknya harus seimbang, yaitu tidak hanya mengembangkan indikator kinerja keuangan saja, melainkan juga indikator kinerja nonkeuangan, antara indikator hasil dengan indikator proses, dan antara indikator kuantitatif dengan indikator kualitatif. Indikator keuangan hanya menekankan pada input dan output yang terbatas pada anggaran dan realisasinya. Sementara indikator nonkeuangan lebih menekankan pada outcome, seperti kepuasan pelanggan, kualitas layanan, cakupan layanan. Pengukuran kinerja VFM dapat membuat keseimbangan antara pengukuran hasil dengan pengukuran proses. Indikator efektivitas dalam VFM berorientasi pada hasil dan lebih bersifat kualitatif, sedangkan indikator ekonomi dan efisiensi lebih berorientasi pada proses dan lebih bersifat kuantitatif.

\section{Pengukuran Ekonomi}

Ekonomi adalah hubungan antara pasar dan masukan (cost of input). Dengan kata lain, ekonomi terbaik yang dimungkinkan (Mardiasmo, 2009). Mahmudi (2007) mengartikan ekonomi sebagai perbandingan antara input sekunder (bahan baku, personel, dan infrastruktur) dengan input primer (kas). Dalam konteks organisasi pemerintahan, ukuran ekonomi berupa berapa anggaran yang dialokasikan untuk membiayai aktivitas tertentu, Apabila sumber daya yang dikeluarkan berada di bawah anggaran maka terjadi penghematan, sedangkan sebaliknya, apabila di atas anggaran maka terjadi pemborosan. Sehingga pada pengukuran ekonomi berhubungan dengan menjawab pertanyaan-pertanyaan sebagai 
berikut (Mardiasmo, 2009: 133): (1) Apakah biaya organisasi lebih besar dari yang telah dianggarkan oleh organisasi? (2) Apakah biaya organisasi lebih besar dari biaya organisasi lain yang sejenis yang dapat diperbandingkan? (3) Apakah organisasi telah menggunakan sumber daya keuangannya secara optimal?

\section{Pengukuran Efisiensi}

Efisiensi merupakan hal penting dari ketiga pokok bahasan value for money. Efisiensi diukur dengan rasio antara output dengan input. Semakin besar output dibanding input, maka semakin tinggi tingkat efisiensi suatu organisasi (Mardiasmo, 2009). Ukuran efisiensi mengukur biaya atas output (cost of output). Ukuran efisiensi mengukur seberapa baik organisasi mampu memanfaatkan sumber daya yang dimilikinya untuk menghasilkan output Mahmudi, 2007).

Dalam pengukuran kinerja value for money, efisiensi dapat dibagi menjadi dua, yaitu (1) efisiensi alokasi (efisiensi 1) dan (2) efisiensi teknis atau manajerial (efisiensi 2). Efisiensi alokasi terkait dengan kemampuan untuk mendayagunakan sumber daya input pada tingkat kapasitas optimal. Efisiensi teknis (manajerial) terkait dengan kemampuan mendayagunakan sumber daya input pada tingkat output tertentu. Pengertian efisiensi berhubungan erat dengan konsep produktivitas. Pengukuran efisiensi dilakukan dengan menggunakan perbandingan antara output yang dihasilkan terhadap input yang digunakan. Ukuran produktivitas atau efisiensi belum mengindikasikan efektivitas. Ukuran efisiensi lebih bersifat relatif, proses kegiatan operasional dapat dikatakan efisien apabila suatu produk kalau hasil kerja tertentu dapat dicapai dengan penggunaan sumber daya dan dana yang serendah-rendahnya (spending well). Perbaikan terhadap efisiensi dapat dilakukan dengan beberapa cara, antara lain (Mardiasmo, 2009: 134): (1) meningkatkan output pada tingkat input yang sama; (2) meningkatkan output dalam proporsi yang lebih besar dari pada proporsi peningkatan input; (3) menurunkan input pada tingkat output yang sama; dan menurunkan input pada tingkat proporsi yang lebih besar daripada proporsi peningkatan output.

Indikator efisiensi menggambarkan hubungan antara masukan sumber daya oleh suatu unit organisasi (misalnya: stat, upah, biaya admlnistratif) dan keluaran yang dihasilkan indikator tersebut memberikan informasi tentang konversi masukan menjadi keluaran (yaitu efisiensi dari proses internal). Dalam implementasinya, untuk mengukur efisiensi organisasi sektor publik dapat menggunakan teknik tertentu, seperti data envelopment analysis (DEA). DEA adalah sebuah teknik yang didasarkan pada pemrograman linear yang membantu analis untuk mengukur dan memperbaiki kinerja dari sebuah agen, program, layanan, atau "keputusan unit" lainnya dengan memperkenankan mereka untuk menentukan efisiensi relatifnya (Gianakis dan McCue, 1999). Pengukuran efisiensi dengan teknik DEA ini cocok untuk organisasi sektor publik, karena karakteristik organisasi sektor publik yang lebih menghasilkan output bersitat nonkeuangan dan lebih dari satu output. Dengan kata lain, organisasi sektor publik menghasilkan sejumlah output yang sering kali tidak dapat dikurangi menjadi pengukuran tunggal. Beberapa penelitian telah menggunakan teknik DEA untuk mengetahui tingkat efisiensi anggaran pemerintah daerah baik secara keseluruhan (lihat Sebayang, 2005), maupun bidang tertentu misalnya pendidikan, kesehatan, dan lain-lain (lihat Pertiwi, 2007).

\section{Pengukuran Efektivitas}

Efektivitas adalah ukuran berhasil tidaknya suatu organisasi mencapai tujuannya. Apabila suatu organisasi berhasil mencapai tujuan, maka organisasi tersebut telah berjalan dengan efektif. Efektivitas hanya melihat apakah suatu program atau kegiatan telah mencapai kegiatan yang telah ditetapkan. Pengukuran efektivitas mengukur hasil akhir dari suatu pelayanan dikaitkan dengan outputnya (cost of outcome). Indikator efektivitas menggambarkan jangkauan akibat dan dampak (outcome) dari keluaran (output) program dalam mencapai tujuan program. Semakin kontribusi output yang dihasilkan berperan terhadap pencapaian tujuan atau sasaran yang ditcntukan, maka semakin efektif proses kerja suatu unit organisasi. Pengukuran efektivitas bisa dilakukan hanya dengan mengukur outcome. Suatu pelayanan mungkin dilakukan secara efisien, namun belum rentu efektif jika pelayanan tersebut tidak menambah nilai bagi pelanggan. Oleh karena itu, indikator efisiensidan efektivitas harus digunakan secara bersama-sama. Jika suatu program dinyatakan efektif dan efisien, maka program tersebut dapat dikatakan cost-effectiveness.

Dari uraian di atas, jelaslah bahwa ketiga pokok bahasan dalam value for money sangat terkait satu dengan yang lainnya. Ekonomi membahas mengenai masukan (input), efisiensi membahas mengenai masukan (input), dan keluaran (output), dan efektivitas membahas mengenai output dan dampak (outcome). 


\section{KONSEP DASAR: INPUT, OUTPUT, DAN OUTCOME}

Organisasi sektor publik untuk melakukan pengukuran kinerja, perlu mengidentifikasi variabel kunci yang nantinya akan dikembangkan menjadi indikator kinerja bagi unit kerja yang bersangkutan. Istilah ukuran kinerja pada dasarnya berbeda dengan istilah "indikaror kinerja". Ukuran kinerja mengacu pada penilaian kinerja secara langsung, sedangkan indikator kinerja mengacu pada penilaian kinerja secara tidak langsung, yaitu hal-hal yang sifatnya hanya merupakan ndikasi-indikasi kinerja.

Di sisi lain, inti dari pengukuran kinerja pada organisasi pemerintahan adalah implementasi konsep VFM. VFM memiliki tiga komponen, yaitu: ekonomi, efisien, dan efektif. Untuk dapat mengukur tingkat ekonomi, efisiensi, dan efektivitas, organisasi pemerintahan harus dapat mengetahui tingkat input, output, dan outcome. Oleh karena itu, indikator kinerja mng dikembangkan meliputi indikator input, indikator output, dan indikator outcome. Sebenamya pada saat diberlakukannya Kepmendagri Nomor 29 Tahun 2002, pengukuran sinerja pemerintah (daerah) tidak hanya sampai pengukuran outcome, tetapi sampai dengan mengukur benefit dan impact. Namun, semenjak dikeluarkannya Permendagri Nomor 13 Tahun 2006 sebagai pengganti dari Kepmendagri Nomor 29 Tahun 2002, pengukuran kinerja hanya sampai pada pengukuran outcome. Sebelum menjelaskan tentang konsep dasar menentukan indikator input, ouput, dan outcome, perlu diketahui terlebih dahulu karakteristik indikator kinerja yang baik dan peranannya dalam organisasi pemerintahan.

Mahmudi (2007: 89) menyebutkan bahwa indikator kinerja sektor publik yang akan dikembangkan nendaknya memiliki karakterisrik, yaitu: sederhana dan mudah dipahami, dapat diukur, dapat dikuantifikasikan, dapat dikaitkan dengan standar atau target kinerja, berfokus pada pelayanan publik, kualitas, dan efisiensi, dikaji secara teratur.

Pengawasan (monitoring) dan kaji ulang terhadap indikator yang telah harus terus dilakukan sebagai upaya untuk meningkatkan perbaikan dan peningkatan kualitas pelayanan, serta sebagai upaya untuk menciptakan budaya perbaikan kinerja secara berkelanjutan. Kaji ulang terhadap indikator kinerja secara rutin bertujuan untuk menguji validitas dan keandalan indikator yang dibuat agar dapat menyesuaikan dengan perubahan kebutuhan layanan, sehingga dalam jangka panjang menghasilkan ukuran kinerja yang lebih baik dan efektif. Sedangkan, dalam organisasi pemerintahan indikator kinerja memiliki peran, antara lain (Mardiasmo, 2009: 128): (1) untuk membantu memperjelas tujuan organisasi; (2) untuk mengevaluasi target akhir (final outcome) yang dihasilkan; (3) sebagai masukan untuk menentukan skema insentif manajerial; (4) memungkinkan bagi pemakai jasa layanan pemerintah untuk melakukan pilihan; (5) untuk menunjukkan standar kinerja; (6) untuk menunjukkan efektivitas; (7) untuk membantu menentukan aktivitas yang memiliki efektivitas biaya paling baik untuk mencapai target sasaran; dan (8) untuk menunjukkan wilayah, bagian, atau proses yang masih potensial untuk dilakukan penghematan biaya.

Agar indikator kinerja dapat berperan seperti disebutkan di atas, maka perlu memahami konsep dasar pembuatan indikator input, output, dan outcome. Konsep dasar indikator input, output, dan outcome terdiri atas definisi dan konsep pengukuran masingmasing jenis indikator. Selain itu, untuk menentukan indikator kinerja perlu mempertimbangkan komponen sebagai berikut (Mahmudi, 2007: 90; Mardiasmo, 2009: 125): (1) Biaya pelayanan; indikator biaya biasanya diukur dalam bentuk biaya unit (unit cost); (2) Tingkat penggunaan; indikator penggunaan (utilization) pada dasamya membandingkan antara jumlah pelayanan yang ditawarkan (supply of service) dengan permintaan publik (public demand); (3) Kualitas dan standar pelayanan; indikator kualitas dan standar pelayanan merupakan indikator yang paling sulit diukur, karena menyangkut pertimbangan yang sifatnya subjektif; (4).

Cakupan pelayanan; diperlukan untuk mengetahui tingkat penyediaan pelayanan yang diberikan dengan permintaan pelayanan yang dibutuhkan; (5) Kepuasan; indikator kepuasan biasanya diukur melalui metode jejak pendapat secara langsung. Bagi pemerintah daerah, metode penjaringan aspirasi masyarakat (need assessment) dapat juga digunakan untuk menetapkan indikator kepuasan.

\section{Indikator Input}


Input adalah semua jenis sumber daya masukan yang digunakan dalam suatu proses tertentu untuk menghasilkan output. Input dibagi menjadi dua, yaitu input primer dan sekunder. Input primer berupa kas, sedangkan input sekunder adalah berupa bahan baku, personel, infrastruktur, dan masukan lainnya yang digunakan untuk menghasilkan output tertentu. Input primer harus diubah menjadi input sekunder untuk diolah menjadi output terrentu. Pengukuran input adalah pengukuran sumber daya yang dikonsumsi oleh suatu proses dalam rangka menghasilkan output. Proses tersebut dapat berbentuk program atau kegiatan. Ukuran input mengindikasikan jumlah sumber daya yang dikonsumsi untuk suatu program. aktivitas, dan organisasi. Pengukuran input dilakukan dengan cara membandingkan input sekunder dengan input primer, atau dengan kata lain sama dengan pengukuran ekonomi untuk mengetahui biaya per unit input (cost of input). Biaya input tersebut diidentitikasi melalui akuntansi biaya dengan sistem pembiayaan (costing). Indikator input saja tidak cukup bila tidak diikuti dengan penentuan indikator output. Artinya, pengukuran ekonomi saja tidak cukup tanpa diikuti dengan efisiensi dalam proses.

\section{Indikator Output}

Output adalah hasil langsung dari suatu proses. Pengukuran output adalah pengukuran keluaran yang dihasilkan dari proses. Ukuran output menunjukkan hasil implementasi prgram atau aktivitas, Sudrajat (2007: 197) menyatakan bahwa pengukuran output harus miliki karakterisrik sebagai berikut: (1) Ditujukan ke bidang kinerja sesungguhnya, yaitu berupa output yang benar-benar menunjukkan kinerja yang diharapkan; (2) Tepat sasaran, dalam artian tidak hanya mencerminkan estimasi kasar; (3) Tepat waktu, objektif, dalam artian tidak dapat dimanipulasi. Jika pengukuran output tidak memiliki salah satu dari empat karakteristik di atas, maka sistem pengendalian yang berorientasi kepada output kemungkinan besar akan mengalami kegagalan. Secara umum, pengukuran output dapat berbentuk kuantitatif dan keuangan, atau kuantitatif dan nonkeuangan. Contoh output yang kuantitatif keuangan adalah jumlah Pendapatan Asli Daerah (PAD) yang berhasil diperoleh oleh bagian pendapatan, sedangkan contoh output kuantitatif nonkeuangan adalah jumlah lulusan yang dihasilkan oleh perguruan tinggi pada periode tertentu, dan sebagainya.

\section{Indikator Outcome}

Outcome adalah dampak suatu program atau kegiatan terhadap masyarakat. Outcome lebih tinggi nilainya dari pada output, karena output hanya mengukur hasil tanpa mengukur ampaknya terhadap masyarakat, sedangkan outcome mengukur kualitas output dan dampak yang dihasilkan. Dengan kata lain, outcome adalah hasil yang dicapai dari suatu program atau kegiatan dibandingkan dengan hasil yang diharapkan. Contohnya, misalnya pemerintah mengeluarkan sejumlah dana untuk kegiatan pencegahan penyakit malaria. Input primernya adalah jumlah dana yang dikeluarkan, sedangkan input sekundernya bisa berupa pembelian obat-obatan, vaksinasi, tenaga medis, dan peralatan medis.

Output-nya adalah bisa orang yang diberi vaksinasi atau wilayah tertentu yang dijadikan sasaran pencegahan penyebaran malaria. Outcome-nya adalah wilayah tertentu terhindar dari wabah penyakit malaria, atau penyakit malaria dapat dicegah penyebarannya dari wilayah tertentu. Pengukuran outcome dilakukan untuk mengukur nilai dari suatu kegiatan atau program. Pengukuran output ebih bersifat mengukur kuantitas barang atau jasa yang dihasilkan oleh suatu aktivitas, sedangkan pengukuran outcome mengukur nilai kualitas dari output tersebut. Pengukuran utcome adalah pengukuran dampak sosial suatu aktivitas, Pengukuran outcome tidak dapat dilakukan sebelum hasil yang diharapkan dari suatu program atau kegiatan ditetapkan, dan pengukuran outcome tidak dapat dilakukan sebelum suatu program atau kegiatan tersebut selesai dilakukan atau telah mencapai tahap tertentu.

\section{KONSEP BEST VALUE}

Konsep best value merupakan perluasan dari konsep Value For Money (VFM) (Mahmudi, 2007). Dalam konteks organisasi sektor publik, konsep best value merupakan suatu konsep yang mewajibkan unit kerja pemerintah pemberi pelayanan publik untuk memberikan pelayanan terbaik (best value). Pemerintah harus mengidentifikasi dan pengelom-pokkan unit kerja mana yang termasuk dalam unit kerja best value. Unit kerja yang termasuk kategori unit kerja best value fokus memberikan perbaikan pelayanan secara terus-menerus dengan cara mengombinas prinsip ekonomi, efisien, dan 
efektif dalam pelayanan, serta harus ranggap terhadap kebut masyarakat.

Pelayanan yang diberikan tidak didasarkan pada ketersediaan dana, melainkan yang menjadi kebutuhan masyarakat. Unit kerja best value bukan merupakan unit yang menjalankan fungsi pendapatan. Hal ini berarti unit kerja rersebut tidak mendas peningkatan pelayanannya pada kenaikan pendapatan yang diperolehnya. Cara ber unit kerja ini tidak dimulai dari bagaimana meningkatkan pendapatan untuk meningka pelayanan, akan tetapi bagaimana memperbaiki dan meningkatkan pelayanan masyarakat sesuai dengan kebutuhan masyarkat baru kemudian mencari solusi bagai membiayai pelayanan tersebut. Salah satu negara yang menerapkan konsep best value, di negara Inggris yang diatur dalam Local Govemment Act 1999.

Karakteristik utama konsep best value adalah penetapan serangkaian indikator untuk mengukur kinerja unit kerja pemberi layanan yang merupakan unit kerja best indikator kerja ditetapkan untuk menilai kinerja dan kesehatan organisasi secara keseluruhan indikator kerja yang digunakan untuk menilai kinerja organisasi adalah indikator output (hasil), sedangkan indikator input dan output digunakan untuk menilai level kegi Setiap unit kerja yang ditunjuk sebagai otoritas best value akan menyusun target yang mencerminkan pencapaian tujuan dan prioritas. Untuk mengimplementasikan best value, tentunya tidak hanya dibutuhkan keseriusan pemerintah, melainkan juga apa publik yang berkompeten untuk menjalankan unit kerja best value.

\section{IMPLEMENTASI PENGUKURAN KINERJA DI PEMERINTAH}

Mahmudi (2007) menyatakan

bahwa manajemen kinerja yang terintegrasi (integrated performance management) terdiri atas dua bagian utama, yaitu perencanaan kinerja pengukuran kinerja. Perencanaan kinerja terdiri atas empat tahap, yaitu: (1) penentuan visi, misi, dan tujuan (goal), serta strategi; (2) penerjemahan visi, misi, dan tujuan, serta strategi ke dalam sasaran strategis, inisiatif strategis, indikator kinerja, target kinerja; (3) penyusunan program; (4) penyusunan anggaran. Sementara itu, pengukuran kinerja value for money dibangun atas tiga komponen utama yaitu: (1) komponen visi, misi, sasaran, dan target; (2) komponen input, proses, output, dan outcome; (3) komponen pengukuran ekonomi, efisiensi, dan efektivitas.

Sejak dikeluarkannya UU Nomor 17 Tahun 2003 tentang Keuangan Negara, perubahan mendasar pada sistem penganggaran di Indonesia, yaitu diterapkannya

Aggaran terpadu (unified budgeting), penganggaran berbasis kinerja (performancebased budgeting), dan penganggaran dengan perspektif jangka menengah (medium term expenditure framework (MTEF). Pada tahun 2005 terbitlah PP Nomor 58 Tahun 2005 tentang pengelolaan Keuangan Daerah yang kemudian diikuti dengan Permendagri Nomor 13 Tahun jo. Permendagri Nomor 59 Tahun 2007 tentang Pedoman Pengelolaan Keuangan. Menurut PP Nomor 58 Tahun 2005 Pasal 38 ayat 2 dinyatakan bahwa penyusunan anggaran berdasarkan prestasi kerja dilakukan berdasarkan capaian kinerja, indikator kinerja, analisis standar belanja (ASB), standar satuan harga, dan standar pelayanan minimal (SPM). Diantara komponen-komponen anggaran berbasis kinerja (ABK) tersebut, indikator kinerja, dan SPM merupakan instrumen penganggaran yang terpenting (Australia Indonesia Partnership, 2008). Skema keterkaitan instrumen-instrumen dalam sistemABK.

Tahap perencanaan kinerja dimulai dengan tahap menentukan visi, misi, tujuan, sasaran, target. Pada tahap ini dituangkan dalam dokumen rencana strategis (renstra). Renstra dihasilkan melalui kombinasi dua pendekatan, yaitu pendekatan top down dan bottom up. Renstra yang dihasilkan dari pendekatan top down merupakan inisiatif dari pemerintah merupakan penjabaran dari visi dan misi kepala daerah. Dari renstra kemudian diterjemahkan dalam rencana kerja.

Sedangkan, renstra yang berasal dari pendekatan bottom up merupakan hasil penjaringan aspirasi masyarakat yang diwujudkan dalam bentuk pelayanan publik. Pelaya publik yang harus disediakan pemerintah kemudian dapat berbentuk standardisasi yang tertuang dalam SPM maupun tidak. SPM dapat juga merupakan bentuk dari implemen konsep best value, karena menurut PP Nomor 65 Tahun 2005 tentang Pedoman Penyusu dan Penerapan SPM Pasal 1 ayat 6, SPM merupakan ketentuan tentang jenis dan $\mathrm{m}$ pelayanan dasar yang merupakan urusan wajib daerah. Pernyataan tersebut mengisyaratkan bahwa SPM merupakan pelayanan yang diselenggarakan pemerintah secara tepat syarat hingga menghasilkan mutu tertentu. Hal ini berarti bahwa SPM disusun berdasarkan kebutuhan masyarakat, dan 
pemerintah wajib berusaha bagaimana memenuhi kebutuhan masyarakat tersebut, termasuk membiayainya.

Standardisasi pelayanan tersebut kemudian dijabarkan dalam standar belanja yang disebut dengan ASB dan program kegiatan yang di dalamnya dicantumkan tolok ukur kinerjanya. ASB dan tolok ukur kinerja menjadi instrumen penting dalam ABK yang berbentuk rencana kerja. Jadi, ASB dan tolok ukur kinerja menjadi dasar dalam menyusun rencana kerja. Rencana kerja ini harus terkait atau selaras dengan rencana srrategis pemerintah. Rencana kerja yang memuat program dan kegiatan sebagai penjabaran dari visi, misi, tujuan: dan strategi pemerintah disebut dengan rencana kerja pemerintah (RK rencana kerja pemerintah daerah (RKPD). Sedangkan, rencana kerja yang berisi kegiatan tolok ukur kinerja, jenis indiaktor, target kinerja, sasaran kegiatan, dan usulan anggaran disebut dengan rencana kerja anggaran (RKA). RKA merupakan dokumen yang mengaitkan pengukuran kinerja value for money melalui indikator input, output, outcome dengan nilai usulan anggaran (belanja, pendapatan, dan pembiayaan).

Struktur RKA, terdiri atas tiga bagian utama, yaitu pada bagian pertama berisi program dan kegiatan beserta lokasinya serta perkiraan anggaran saat ini tahun $n$ ) dan prakiraan anggaran maju (tahun $\mathrm{n}+1$ ) berdasarkan rencana strategis yang telah diterapkan oleh pemerintah daerah. Perkiraan maju merupakan bentuk implementasi MTEF yang berisi perkiraan kebutuhan anggaran untuk program dan kegiatan yang direncanakan dalam tahun anggaran berikutnya dari tahun anggaran yang direncanakan. Program dan anggaran yang tertuang dalam RKA tidak boleh menyimpang dari program dan kegiatan yang telah ditetapkan dalam rencana strategis pemerintah daerah.

Bagian kedua merupakan bentuk pengukuran kinerja VFM yang berisi indikator dan tolok ukur kinerja dari program dan kegiatan yang terkait. Indikator dan tolok ukur kinerja kegiatan tersebut harus sesuai dengan yang tercantum pada SPM dan rencana strategis yang telah ditetapkan. Dari indikator dan tolok ukur kinerja tersebut kemudian dapat dijabarkan dalam rincian anggaran, yang mempakan bagi ketiga pada RKA. Usulan anggaran tersebut harus dianggarkan secara wajar. Artinya, anggaran yang diusulkan harus memiliki keterkairan logis dengan kegiatan dan tolok ukur kinerjanya. Oleh karena itu, untuk menilai kewajaran atas beban kerja dan biaya terhadap suatu kegiatan diperlukan ASB dan standar satuan harga.

Analis standar biaya juga dapat digunakan sebagai data pembanding yang bermanfaat untuk menilai efisiensi dan efektivitas ABK. Ritonga (2010: 9) menjelaskan bahwa dengan adanya data pembanding, memungkinkan untuk menilai apakah program dan kegiatan yang direncanakan lebih efisien dan lebih efektif dibandingkan dengan data pembanding tersebut atau program dan kegiatan yang sama di tahun sebelumnya. Suatu program atau kegiatan dikatakan semakin efisien jika untuk mencapai output tertentu diperlukan biaya yang lebih rendah dibandingkan dengan data dasar (benchmark) atau dengan biaya tertentu akan diperoleh output yang lebih besar dibandingkan data dasar dan sebaliknya. Efektivitas dapat dilihat dengan membandingkan rencana output terhadap rencana hasil. Jika dengan rencana output tertentu akan mampu dicapai hasil yang lebih besar atau dengan target hasil tertentu akan dicapai dengan output yang lebih kecil dibandingkan dengan data dasar, maka program dan kegiatan tersebut dikatakan semakin efektif

\section{KESIMPULAN}

Pengukuran kinerja sektor publik bukan hanya bagaimana kemampuan uang publik dibelanjakan, tetapi dilihat juga dari segi ekonomis, efisiensi, dan efektivitas, dan tentunya dari segi outcome. Pengukuran kinerja sektor publik dilaksanakan untuk menilai pencapaian organisasi melalui alat ukur keuangan dan nonkeuangan. Untuk melakukan pengukuran kinerja dengan melihat variabel kunci kemudian dikembangkan Pada unit kerja yang bersangkutan untuk dapat diketahui tingkat pencapaian kinerja, dari sinilah kira bisa mengetahui apakah kinerja suatu organisasi sudah sesuai dengan apa yang direncanakan meliputi ekonomi, efisiensi, efektivitas, dan lain-lain atau tidak. Jika tidak tercapai maka dikatakan bahwa pengukuran kinerja suatu organisasi tidak berjalan sebagaimana mestinya. Tentunya kinerja bukanlah akhir dari segalanya tetapi ini mempakan acuan atau bagi pemerintah atas apa yang telah dilakukannya dalam pengembangan organisasi sektor publik.

\section{DAFTAR PUSTAKA}

1. Australia Indonesia Partnership. 2008. Sistem Penganggaran Keuangan di Indonesia. Dipresentasikan dalam Pelatihan PEACH kerja sama PPE FE-UGM, IASTP III, dan SofEI, Jayapura.

2. Gianakis, GerasimosA., dan Difford P. McCue. 1999. Local Govemment 
Budgeting:A Managerial Approach. USA: Greenwood Publishing Group.

3. Mahmudi, 2007. Manajemen Kinerja Sektor Publik, edisi revisi. Yogyakarta: UPP STIM YKPN.

4. Mardiasmo. 2009. Akuntansi Sektor Publik. Yogyakarta: CV Andi Offset.

5. Pertiwi, Lela Dina. 2007. "Efisiensi Pengeluaran Pemerintah Daerah di Provinsi Jawa Tengah". Jurnal Ekonomi Pembangunan, vol. 12, no. 2, hlm. 123139.

6. Ritonga, Irwan Taufiq. 2010. Analisis Standar Belanja (ASE): Konsep, Metode Pengembangan, dan lmplementasi di Pemerintah Daerah. Yogyakarra: Sekolah Pascasarjana UGM .

10. ta: Universitas Gadjah Mada.
7. Sebayang, Asnita Frida. 2005. "Kinerja Kebijakan Fiskal Daerah di Indonesia Pasca-Krisis". Jurnal Ekonomi Pembangunan, vol. 10, no. 3. hlm. 203214.

8. Sudrajat, Drajat. 2007. "Pengendalian dan Pengawasan Anggaran Daerah dalam Mendukung Terwujudnya Dean Govemment". Diedit oleh Abdul Halim, dalam Seri Bunga Rampai Manajemen Keuangan Daerah: Akuntansi dan Pengendalian Pengelolaan Keuangan Daerah. Yogyakarra: UPP STIM YKPN.

9. Untoro, Wisnu. 2010. "Kepublikan sebagai Pemoderasi Pengaruh Perencanaan Scrategik pada Kinerja Organisasional". Disertasi. Yogyakar 